\title{
The Analysis of the Interest Cost of the Trading Companies in Serbia
}

\author{
Radojko LUKIC ${ }^{1}$ \\ Dragan VOJTESKI KLJENAK ${ }^{2}$
}

\begin{abstract}
Interest costs are a component of operational costs of trading companies. They are covered from the margin. Their size varies depending on the interest rate, foreign exchange rate, investment management efficiency, financial indebtedness, sales and other controlled and uncontrolled determinants. This paper examines the dynamics and factors of the size of the costs of interest rates of trade companies in Serbia for the period 2013 - 2017. The empirical results of the research show a continuous reduction of the interest costs in the last years of the analyzed period. This had a positive effect on the performance of trade companies in Serbia.
\end{abstract}

KEYWORDS: interest costs, financial indebtedness, inventory management, liquidity, efficiency, profitability.

JEL CLASSIFICATION: $L 81, M 31, M 41, O 32$

\section{INTRODUCTION}

Interest costs become an increasingly important component of total - operating costs of trading companies. In view of this, they are the subject of research in this paper, with particular reference to trade companies in Serbia. The purpose of the research is to comprehensively examine the factors of the dynamics of the size of the interest costs of trading companies in Serbia. This should enable the most efficient management of interest costs in order to improve the performance of trading companies in Serbia in the future, in what we see the scientific and professional contribution of this paper.

As is well known, there is extensive literature that deals with the general problem of measuring the significance of gross operating margin (earnings before interest, taxes, depreciation and amortization - EBITDA, and earnings before interest and tax EBIT) in financial reporting for the needs of the most efficient company management (Sui, 2017), which includes interest. In this context, the interest coverage ratio (EBIT / interest rate) is analyzed in particular. However, it is significant that a smaller number of published comprehensive papers are devoted to the specificities of gross operating margin analysis, interest coverage ratio in trading companies (Berman, 2013; Calva, 2017; Carstea et al., 2017; Corona, 2014; Gülşah et al., 2016; Hoe, 2017; Ko et al., 2017; Levy, 2014; Manini, 2017; Špička, 2016; Susmus, 2017; Tan, 2016). This

\footnotetext{
${ }^{1}$ University of Belgrade Faculty of Economics, Republic of Serbia, E-mail: rlukic @ ekof.bg.ac.rs

${ }^{2}$ Faculty of Business Economics and Entrepreneurship, Belgrade, Republic of Serbia, E-mail: vojteski@live.co.uk
} 
particularly applies to literature in Serbia (Lukic, 2017a, b), that is, as far as we know, no work has been published so far as a whole on the issue of the importance of measuring and analyzing gross operational margin and, in that context, the cost of interest in trading companies in Serbia. This emptiness should be, to a certain extent, filled with this paper, which is dedicated to the complex analysis of the factor of the interest costs size, as a component of the gross operating margin, what also gives the reflection of its scientific and professional contribution.

The basic hypothesis of research in this paper is that efficient cost management, primarily by the application of modern concepts, significantly contributes to improving the performance of trading companies. This fully applies to interest costs, especially in the conditions of the financial crisis. Acknowledgement of key determinants of size is a prerequisite for efficient management of interest costs. By applying the certain methodology in this paper we explore the determinants of interest costs size of trading companies in Serbia.

In conducting the research in this paper we used the methodology based on comparative analysis, financial analysis, ratio analysis and the application of the strategic profit model. To a certain extent, the statistical analysis was also used.

In order to conduct the research in this paper we collected empirical data from the Agency for Business Registers of the Republic of Serbia. Furthermore, empirical data were also collected from financial statements of selected retail chains and their websites (CSI Market company). For trade companies in Serbia, empirical data were "produced" according to a unique methodology, so they can be comparable internationally and, in this respect, there are no restrictions whatsoever.

\section{IMPORTANCE OF TRADE COMPANIES IN SERBIA}

The importance of trading companies will be envisaged through participation of the 100 largest companies in Serbia, in respect to their business revenues. Table 1 shows the participation of wholesale and retail trade companies in the 100 largest companies, considering their business revenues in 2017.

Table 1. Participation of trade companies in the $\mathbf{1 0 0}$ largest companies according to business revenues in Serbia

\begin{tabular}{|c|c|}
\hline & $\begin{array}{c}\text { Participation in 100 largest companies - according } \\
\text { to operating revenues in 2017, (\%) }\end{array}$ \\
\hline Wholesale & 5.3 \\
\hline Nelt Co. & 0.8 \\
\hline Phoenix Pharma & 0.4 \\
\hline Mercata & 0.4 \\
\hline Other wholesale companies & 3.3 \\
\hline Retail & 3.6 \\
\hline Delhaize Serbia & 1.0 \\
\hline Mercator-S & 0.9 \\
\hline MOL Serbia & 0.4 \\
\hline Lukoil Serbia & 0.3 \\
\hline Other retail companies & 1.0 \\
\hline
\end{tabular}

Source: Agency for Business Registers of the Republic of Serbia 
The data in the table show that the wholesale companies participated in the 100 largest companies according to business revenues in Serbia in 2017 with 5.3\% and in retail trade with $3.3 \%$. Observation of individual trading companies' data shows that the largest share was registered with Delhaize Serbia and Mercator-S. The share itself reflected on the size of the costs (including interest) and revenues, that is - the performance of trading companies in Serbia.

\section{DYNAMICS OF THE SIZE OF INTEREST COSTS OF TRADING COMPANIES IN SERBIA}

Numerous factors influence on the size of interest costs in trading companies, such as: bank interest rate, exchange rate, liquidity, financial indebtedness, efficiency and profitability. Their effective control can be "optimized". Table 2 shows the dynamics of the interest rate and foreign exchange rates in Serbia.

Table 2. Interest rate (in \%, annually) and dinar exchange rate against foreign currency (average period) in Serbia

\begin{tabular}{|c|c|c|}
\hline & Reference interest rate & EURO \\
\hline 2013 December & 9.50 & 114.6421 \\
\hline 2014 December & 8.00 & 120.9583 \\
\hline 2015 December & 4.50 & 121.6261 \\
\hline 2016 December & 4.00 & 123.4723 \\
\hline 2017 December & 3.50 & 118.4727 \\
\hline 2018 October & 3.00 & 118.3198 (2018 November) \\
\hline
\end{tabular}

Source: National Bank of Serbia

The data in the given table show that in the observed period the reference interest rate decreased from year to year. The exchange rate of the dinar against the euro is almost stable. This has a positive effect on the movement of interest costs, net interest costs of all companies in Serbia, including trade companies.

Net interest costs are determined by the formula:

Net interest costs $=$ Interest costs - Interest income

Table 3 shows parallel between the net interest costs in processing industry and trade in Serbia for the period 2013-2017.

Table 3. Net interest costs of processing industry and trade companies in Serbia

\begin{tabular}{|c|c|c|c|c|c|c|c|c|c|c|}
\hline & \multicolumn{4}{|c|}{ Processing industry } & \multicolumn{4}{c|}{ Trade } \\
\cline { 2 - 12 } & $\begin{array}{c}\text { Interest } \\
\text { costs } \\
\text { (million } \\
\text { dinars) }\end{array}$ & $\begin{array}{c}\text { Interest } \\
\text { revenue } \\
\text { (million } \\
\text { dinars) }\end{array}$ & $\begin{array}{c}\text { Net interest } \\
\text { costs } \\
\text { (million } \\
\text { dinars)* }\end{array}$ & $\begin{array}{c}\text { Interest } \\
\text { costs (in } \\
\% \text { from } \\
\text { revenue) }\end{array}$ & $\begin{array}{c}\text { Net } \\
\text { interest } \\
\text { costs (in } \\
\% \text { from } \\
\text { revenue)* }\end{array}$ & $\begin{array}{c}\text { Interest } \\
\text { costs } \\
\text { (million } \\
\text { dinars) }\end{array}$ & $\begin{array}{c}\text { Interest } \\
\text { revenue } \\
\text { (million } \\
\text { dinars) }\end{array}$ & $\begin{array}{c}\text { Net interest } \\
\text { costs } \\
\text { (million } \\
\text { dinars) }\end{array}$ & $\begin{array}{c}\text { Interest } \\
\text { costs (in } \\
\% \text { from } \\
\text { revenue) }\end{array}$ & $\begin{array}{c}\text { Net } \\
\text { interest } \\
\text { costs (in } \\
\text { (revenue) } \\
\text { rev }\end{array}$ \\
\hline 2013 & 38.049 & 9.950 & 28.099 & 1.72 & 1.27 & 23.864 & 9.401 & 14.463 & 0.82 & 0.50 \\
\hline 2014 & 45.376 & 4.758 & 40.618 & 2.03 & 1.82 & 24.194 & 6.558 & 17.636 & 0.86 & 0.62 \\
\hline 2015 & 35.745 & 4.299 & 31.446 & 1.48 & 1.30 & 19.758 & 4.737 & 15.021 & 0.66 & 0.50 \\
\hline 2016 & 27.569 & 2.876 & 24.693 & 1.05 & 0.94 & 15.160 & 3.466 & 11.694 & 0.46 & 0.35 \\
\hline 2017 & 28.188 & 2.283 & 25.905 & 0.99 & 0.91 & 15.383 & 3.056 & 12.327 & 0.44 & 0.36 \\
\hline Median & 35745.0000 & 4299.0000 & 28099.0000 & 1.4800 & 1.3000 & 19758.0000 & 4737.0000 & 14463.0000 & 6600 & 5000 \\
\hline
\end{tabular}

Note: *Calculations performed by the author. The Median was determined in the SPSS software

Source: Agency for Business Registers of the Republic of Serbia 
Interest costs, i.e. net interest costs, show a declining trend in Serbia, both in processing industry and trade. They are lower than in trade in the United States (Table 4), what has positively affected their overall performance.

Table 4. Interest Rates in US Trade

\begin{tabular}{|c|c|}
\hline & Interest costs in \% from net sales, 4Q 2017 \\
\hline Production & 2.11 \\
\hline Wholesale & 0.60 \\
\hline Retail & 0.75 \\
\hline
\end{tabular}

Source: U.S. Census Bureau, Washington, DC 20233 Quarterly Financial Report for Manufacturing, Mining, Trade, and Selected Service Industries. Third Quarter 2018, Series QFR/1 8- Q3, Retrieved fromhttps://www.census.gov/econ/qfr/mmws/current/qfr_pub.pdf (December 24, 2018)

The size of the interest cost was to a significant extent determined by investment activities. Table 5 and Figure 1 show the investment activity, measured by the size of assets, trade companies in Serbia, for the period $2013-2017$.

Table 5. Investments of trade companies in Serbia

\begin{tabular}{|c|c|c|}
\hline & Assets (million dinars) & Index* $^{*}$ \\
\hline 2013 & 2.160 .474 & 98.8 \\
\hline 2014 & 2.077 .002 & 96.1 \\
\hline 2015 & 2.234 .368 & 107.5 \\
\hline 2016 & 2.311 .644 & 103.4 \\
\hline 2017 & 2.393 .721 & 103.5 \\
\hline $\begin{array}{c}\text { (CAGR - Compound Annual } \\
\text { Growth Rate)* }\end{array}$ & $2.07 \%$ & \\
\hline
\end{tabular}

Note: *Calculations performed by the author

Source: Business Registers Agency of the Republic of Serbia

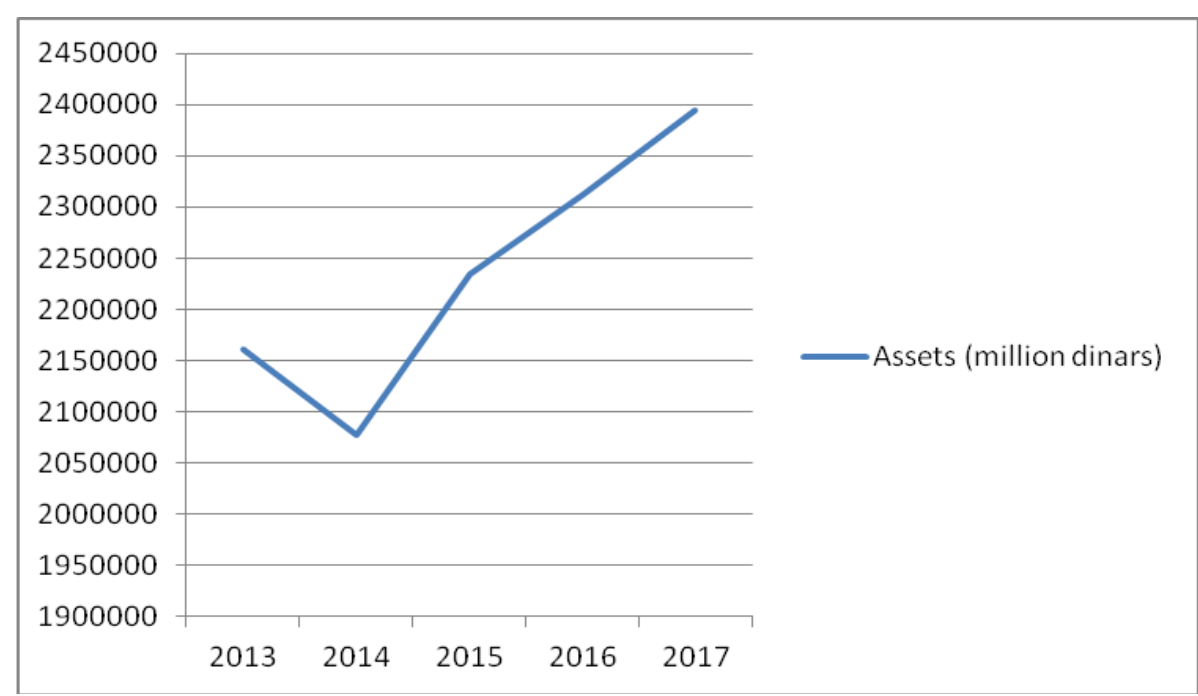

Figure 1. Investments of trade companies in Serbia

Investment activities of trading companies in Serbia have been intensified in recent years. The annual growth rate of assets is $2.07 \%$. This has significantly influenced on the size of the interest 
costs of trading companies in Serbia (according to the results of regression analysis: $\mathrm{R}^{2}=, 889$, $\mathrm{F}=33.143$, Sig. $=, 010)$.

Table 6 shows the investment indicators of some member states of the European Union and Serbia for 2016.

Table 6. Investment indicators of selected EU Member States and Serbia in 2016

\begin{tabular}{|c|c|c|}
\hline & $\begin{array}{c}\text { Investments per employee } \\
\text { (thousand Euros) }\end{array}$ & $\begin{array}{c}\text { Investment rate (investments / } \\
\text { added value per factor costs) }\end{array}$ \\
\hline Germany & 4.0 & 8.4 \\
\hline France & 5.9 & 11.4 \\
\hline Croatia & 2.1 & 10.9 \\
\hline Italy & 4.0 & 10.1 \\
\hline Slovenia & 4.9 & 14.1 \\
\hline Serbia* & 2.1 & 18.0 \\
\hline
\end{tabular}

Note: *Calculations performed by the author

Source: Euro stat and Statistical Yearbook of the Republic of Serbia 2018.

Technical equipment in Serbia's trade is therefore lower than in Germany, France, Italy and Slovenia. It is at the same level as in Croatia. The investment rate in Serbia's trade is higher than in the observed countries. In addition to its influence on the size of interest costs, it had a positive impact on its overall performance.

\section{LIQUIDIRY AND FINANCIAL INDEBTEDNESS AS A DETERMINANT OF THE SIZE OF THE INTEREST COSTS OF TRADING COMPANIES IN SERBIA}

Liquidity and solvency (financial indebtedness) are important factors of the interest costs size in trading companies. Liquidity is expressed through current liquidity in the following way: current liquidity = working capital / short-term liabilities. It can also be expressed with the size of net working capital, which are determined by the formula: Net working capital = Current assets Short-term liabilities. Net working capital represents a part of working capital financed from long-term sources of funds. Financial indebtedness (as a measure of solvency) is most often defined as the ratio between assets and capital, i.e.: financial indebtedness $=$ assets / capital. Table 7 shows the liquidity and financial indebtedness of trade companies in Serbia for the period $2013-2017$.

Table 7. Liquidity and financial indebtedness of trade companies in Serbia

\begin{tabular}{|c|c|c|c|c|c|c|}
\hline & $\begin{array}{c}\text { Current assets } \\
\text { (million dinars) }\end{array}$ & $\begin{array}{c}\text { Short-term } \\
\text { liabilities } \\
\text { (million dinars) }\end{array}$ & $\begin{array}{c}\text { Net working } \\
\text { capital } \\
\text { (million } \\
\text { dinars)* }\end{array}$ & $\begin{array}{c}\text { Net } \\
\text { Current } \\
\text { liquidity* }\end{array}$ & $\begin{array}{c}\text { working } \\
\text { assets (in } \\
\text { \% from } \\
\text { revenue)* }\end{array}$ & $\begin{array}{c}\text { Financial } \\
\text { indebtedness } \\
\text { (assets / } \\
\text { capital) }\end{array}$ \\
\hline 2013 & 1.361 .155 & 1.368 .137 & -6.982 & 0.99 & -0.24 & 2.89 \\
\hline 2014 & 1.318 .032 & 1.299 .874 & 18.158 & 1.01 & 0.64 & 2.82 \\
\hline 2015 & 1.424 .135 & 1.377 .180 & 46.953 & 1.03 & 1.57 & 2.74 \\
\hline 2016 & 1.503 .476 & 1.478 .299 & 25.177 & 1.02 & 0.76 & 2.68 \\
\hline 2017 & 1.568 .615 & 1.470 .677 & 97.938 & 1.07 & 2.83 & 2.56 \\
\hline Median & 1424135.0000 & 1377180.0000 & 25177.0000 & 1.0200 & 0.7600 & 2.7400 \\
\hline
\end{tabular}




\begin{tabular}{|c|c|c|c|c|c|c|}
\hline & $\begin{array}{c}\text { Current assets } \\
\text { (million dinars) }\end{array}$ & $\begin{array}{c}\text { Short-term } \\
\text { liabilities } \\
\text { (million dinars) }\end{array}$ & $\begin{array}{c}\text { Net working } \\
\text { capital } \\
\text { (million } \\
\text { dinars)* }\end{array}$ & $\begin{array}{c}\text { Current } \\
\text { liquidity* }\end{array}$ & $\begin{array}{c}\text { Net } \\
\text { working } \\
\text { assets (in } \\
\text { \% from } \\
\text { revenue)* }\end{array}$ & $\begin{array}{c}\text { Financial } \\
\text { indebtedness } \\
\text { (assets / } \\
\text { capital) }\end{array}$ \\
\hline $\begin{array}{c}\text { (CAGR - } \\
\text { Compound } \\
\text { Annual } \\
\text { Growth } \\
\text { Rate)* }\end{array}$ & $2.88 \%$ & $1.46 \%$ & & & \\
\hline \multicolumn{3}{|c|}{ Note: *Calculations performed by the author. The Median was determined in SPSS software. } \\
Source: Business Registers Agency of the Republic of Serbia
\end{tabular}

Liquidity and financial indebtedness of trading companies in Serbia have been lately improved. The annual growth rate of working capital $(2.88 \%)$ is higher than short-term liabilities $(1.46 \%)$. This had a favourable impact on their costs (including interest) and revenues, i.e. performance.

\section{EFFICIENCY AS A DETERMINANT OF THE INTEREST COSTS SIZE IN TRADING COMPANIES IN SERBIA}

Efficiency affects the size of interest costs in trading companies. This is particularly true of inventory management, bearing in mind their dominant share in working capital. Table 8 shows the efficiency of trading companies in Serbia for the period 2013-2017 (measured by the turnover of assets, working capital, inventories and short-term liabilities).

Table 8. Efficiency of trade companies in Serbia

\begin{tabular}{|c|c|c|c|c|}
\hline & $\begin{array}{c}\text { Assets turnover } \\
\text { ratio (revenues / } \\
\text { assets) }\end{array}$ & $\begin{array}{c}\text { Working assets } \\
\text { turnover ratio } \\
\text { (revenues / working } \\
\text { assets) }\end{array}$ & $\begin{array}{c}\text { Short-time } \\
\text { Inventory turnover } \\
\text { ratio (revenues / } \\
\text { inventory) }\end{array}$ & $\begin{array}{c}\text { tiabilities } \\
\text { turnover ratio } \\
\text { (revenues / } \\
\text { short-time } \\
\text { liabilities) }\end{array}$ \\
\hline 2013 & 1.34 & 2.12 & 6.00 & 2.11 \\
\hline 2014 & 1.36 & 2.14 & 5.97 & 2.17 \\
\hline 2015 & 1.34 & 2.10 & 5.57 & 2.17 \\
\hline 2016 & 1.43 & 2.20 & 5.65 & 2.23 \\
\hline 2017 & 1.44 & 2.20 & 5.62 & 2.34 \\
\hline Median & 1.3600 & 2.1400 & 5.6500 & 2.1700 \\
\hline
\end{tabular}

Note: Calculations performed by the author. The Median was determined in SPSS software. Source: Business Registers Agency of the Republic of Serbia

According to all shown criteria, the efficiency of trade companies in Serbia has improved year after year in the observed period. This has had a favourable effect on their performance, including the size of interest costs. 


\section{PROFITABILITY AS A FACTOR OF THE INTEREST COSTS SIZE OF TRADING COMPANIES IN SERBIA}

In addition to liquidity, financial indebtedness, efficiency, profitability is also a factor in the interest cost of trading companies. In this paper, it is presented as: return on sales = net profit / sales; return on assets $=$ net profit $/$ assets; and return on equity $=$ net profit $/$ equity.

An integrated approach to profitability analysis is based on a strategic profit model. It shows key determinants of profitability, by which effective control it can be significantly improved.

In order to measure the profitability of trading enterprises in Serbia, we used the strategic profit model, and it is formulated as follows:

$$
\begin{gathered}
\text { Return on assets }=\frac{\text { Netprofit }}{\text { Sales }} \times \frac{\text { Sales }}{\text { Assets }} \\
\text { Return on equity }=\frac{\text { Netprofit }}{\text { Sales }} \times \frac{\text { Sales }}{\text { Assets }} \times \frac{\text { Assets }}{\text { Capital }} \\
\text { Gross margin return on inventory }=\frac{\text { Grossmargin }}{\text { Sales }} \times \frac{\text { Sales }}{\text { Inventories }}
\end{gathered}
$$

Table 9 presents the strategic profit model of trade companies in Serbia for the period 2013 2017.

\begin{tabular}{|c|c|c|c|c|}
\hline & \multicolumn{4}{|c|}{ Return on assets } \\
\hline & $\begin{array}{c}\text { Return on assets } \\
\text { (net profit / } \\
\text { assets), }(\%)=\end{array}$ & $\begin{array}{c}\text { Return on sales (net } \\
\text { profit / revenues), } \\
(\%) \times\end{array}$ & $\begin{array}{l}\text { Assets turnover ratio } \\
\text { (revenues / assets) }\end{array}$ & \\
\hline 2013 & 4.15 & 3.10 & 1.34 & \\
\hline 2014 & 3.81 & 2.81 & 1.36 & \\
\hline 2015 & 4.58 & 3.42 & 1.34 & \\
\hline 2016 & 4.41 & 3.08 & 1.43 & \\
\hline 2017 & 5.29 & 3.67 & 1.44 & \\
\hline \multirow[t]{3}{*}{ Median } & 4.4100 & 3.1000 & 1.3600 & \\
\hline & \multicolumn{4}{|c|}{ Return on capital } \\
\hline & $\begin{array}{c}\text { Return on capital } \\
\text { (net profit / } \\
\text { capital) }=\end{array}$ & $\begin{array}{c}\text { Return on sales (net } \\
\text { profit / revenues), } \\
(\%) x\end{array}$ & $\begin{array}{l}\text { Assets turnover ratio } \\
\text { (revenues / assets) }\end{array}$ & $\begin{array}{c}\text { Financial } \\
\text { indebtedness } \\
\text { (assets / capital) }\end{array}$ \\
\hline 2013 & 12.01 & 3.10 & 1.34 & 2.89 \\
\hline 2014 & 10.77 & 2.81 & 1.36 & 2.82 \\
\hline 2015 & 12.53 & 3.42 & 1.34 & 2.74 \\
\hline 2016 & 11.84 & 3.08 & 1.43 & 2.68 \\
\hline 2017 & 13.58 & 3.67 & 1.44 & 2.56 \\
\hline Median & 12.0100 & 3.1000 & 1.3600 & 2.7400 \\
\hline
\end{tabular}

Table 9. Analysis of the efficiency and profitability of trade companies in Serbia based on the strategic profit model 


\begin{tabular}{|c|c|c|c|c|}
\hline \multirow{2}{*}{} & \multicolumn{4}{|c|}{ Return on inventory } \\
\cline { 2 - 5 } & $\begin{array}{c}\text { Return on } \\
\text { inventory (gross } \\
\text { margin / } \\
\text { inventory), }(\%)=\end{array}$ & $\begin{array}{c}\text { Return on sales } \\
\text { (gross margin / } \\
\text { revenues), (\%) } \mathbf{~}\end{array}$ & $\begin{array}{c}\text { Inventory turnover } \\
\text { ratio (revenues / } \\
\text { inventory) }\end{array}$ & \\
\hline 2013 & 142.66 & 23.01 & 6.20 & \\
\hline 2014 & 145.78 & 23.59 & 6.18 & 5.78 \\
\hline 2015 & 136.58 & 23.63 & 5.78 & \\
\hline 2016 & 136.23 & 23.57 & 5.80 & \\
\hline 2017 & 139.49 & 24.05 & 5.8000 & \\
\hline Median & 139.4900 & 23.5900 & & \\
\hline
\end{tabular}

Note: Calculations performed by the author. The median was determined in SPSS software. Source: Business Registers Agency of the Republic of Serbia

The data in the given table show improved profitability of trade companies in Serbia in 2017 compared to the previous year according to all the presented criteria. Along with other factors it had a favourable effect on their performance, i.e. on the interest costs. The impact of interest costs on the return on assets of trade companies in Serbia $(\mathrm{R} 2=0.7001)$ is significant.

\section{THE RATIO OF INTEREST COVERAGE OF TRADING COMPANIES IN SERBIA}

The significant indicator for managing interest costs is the ratio of interest coverage. Interest coverage ratio is determined as the ratio between earnings before interest and taxes (EBIT) and interest, i.e.

$$
\text { Interestcoverageratio }=\frac{\text { Earningsbeforeinterestandtaxes }}{\text { Interest }}
$$

It shows how many times the interest is covered by earnings before interest and taxes, i.e. provides information on what are the possibilities to cover interest from the realized earnings before interest and taxes. There is no "solid" standard for this ratio, according to some estimates it should be between 3 - 7 and more. It is considered that this ratio is at a satisfactory level, if it increases from year to year (which is achieved by reducing interest through repayment of loans, by not taking new loans and with an increase in earnings before interest and taxes). Weakness is considered to be that it does not say anything about the effects of the principal on the repayment of debts.

Table 10 shows earnings before interest and taxes as a component of interest coverage ratio of trading companies in Serbia. 
Table 10. Earnings before interest and taxes of trading companies in Serbia

\begin{tabular}{|c|c|c|c|c|c|c|}
\hline & $\begin{array}{l}\text { Net profiit } \\
\text { (million } \\
\text { dinars) }\end{array}$ & $\begin{array}{l}\text { interest } \\
\text { (million } \\
\text { dinars) }\end{array}$ & $\begin{array}{c}\text { Tax } \\
\text { (million } \\
\text { dinars) }\end{array}$ & $\begin{array}{c}\text { Earnings } \\
\text { before } \\
\text { interest and } \\
\text { tax } \\
\text { (million } \\
\text { dinars)* }^{*}\end{array}$ & $\begin{array}{c}\text { Earnings } \\
\text { before } \\
\text { interest and } \\
\text { tax } \\
\text { per } \\
\text { employee } \\
\text { (thousand } \\
\text { dinars)* }\end{array}$ & $\begin{array}{l}\text { Earnings } \\
\text { before } \\
\text { interest } \\
\text { and tax } \\
\text { (in \% } \\
\text { from } \\
\text { revenue)* }\end{array}$ \\
\hline 2013 & 89.730 & 23.864 & 10.647 & 124.241 & 643.036 & 4.29 \\
\hline 2014 & 79.234 & 24.194 & 9.494 & 112.922 & 590.682 & 4.00 \\
\hline 2015 & 102.303 & 19.758 & 13.855 & 135.916 & 694.792 & 4.54 \\
\hline 2016 & 102.002 & 15.160 & 16.115 & 133.277 & 646.686 & 4.03 \\
\hline 2017 & 126.734 & 15.383 & 17.496 & 159.613 & 767.296 & 4.62 \\
\hline \multicolumn{7}{|l|}{$\begin{array}{c}\text { Descriptive } \\
\text { Statistics }\end{array}$} \\
\hline Minimum & 79234.00 & 15160.00 & 9494.00 & 112922.00 & 590.68 & 4.00 \\
\hline Maximum & 126734.00 & 24194.00 & 17496.00 & 159613.00 & 767.30 & 4.62 \\
\hline Mean & 100000.6000 & 19671.8000 & 13521.4000 & 133193.8000 & 668.4984 & 4.2960 \\
\hline Std. Deviation & 17753.29704 & 4381.27860 & 3432.11382 & 17295.15775 & 66.39244 & 0.28413 \\
\hline $\begin{array}{c}\text { Valid N } \\
\text { (listwise) }\end{array}$ & 5 & & & & & \\
\hline Global retail & & & & & & $\begin{array}{l}\text { Earnings } \\
\text { before } \\
\text { interest } \\
\text { and tax } \\
\text { (in } \% \text { from } \\
\text { revenue) }\end{array}$ \\
\hline Tesco & & & & & & 1.26 \\
\hline Carrefour & & & & & & 1.80 \\
\hline Ahold Delhaize & & & & & & 7.67 \\
\hline
\end{tabular}

Note: *Calculations performed by the author. Descriptive statistics were made in the SPSS software. Source: Serbian Business Registers Agency, Annual Report Tesco, Carrefour, Ahold Delhaize (2017)

The data in the given table show that on average, earnings before interest and taxes in percentages of revenues in trade companies of Serbia amount to $4.10 \%$. Productivity measured by the ratio between earnings before interest and taxes and employees in Serbia's trading companies increased from year to year over the observed period, and on average it amounted to 668.4984 thousand dinars. This positively reflected on the size of the interest coverage ratio, which is above the standard.

Earnings before interest and taxes can also be taken as a component of a strategic profit model. For the purpose of illustration, in Table 11, a strategic profit model is presented in this form for trading companies in Serbia for 2017. 
Table 11. Strategic profit model with component of earnings before interest and taxes of trading companies in Serbia, 2017

\begin{tabular}{|c|c|c|c|c|}
\hline \multirow{3}{*}{2017} & \multicolumn{4}{|l|}{ Return on assets } \\
\hline & $\begin{array}{l}\text { Return on assets } \\
\text { (EBIT / assets) = }\end{array}$ & $\begin{array}{l}\text { Return on sales } \\
\text { (EBIT / sales) } \mathrm{x}\end{array}$ & $\begin{array}{l}\text { Assets turnover } \\
\text { ratio (revenues / } \\
\text { assets) }\end{array}$ & \\
\hline & 6.65 & 4.62 & 1.44 & \\
\hline & \multicolumn{4}{|l|}{ Return on capital } \\
\hline \multirow[t]{2}{*}{2017} & $\begin{array}{l}\text { Return on capital } \\
(\text { EBIT / capital }))=\end{array}$ & $\begin{array}{l}\text { Return on sales } \\
\text { (EBIT / sales) } x\end{array}$ & $\begin{array}{l}\text { Assets turnover } \\
\text { ratio (revenues / } \\
\text { assets)x }\end{array}$ & $\begin{array}{l}\text { Financial } \\
\text { indebtedness (assets } \\
\text { / capital) }\end{array}$ \\
\hline & 17.03 & 4.62 & 1.44 & 2.56 \\
\hline
\end{tabular}

Note: Calculations performed by the author. Instead of earnings before interest and taxes - EBIT in a strategic profit model, EBITDA - earnings before interest, taxes, depreciation and depreciation can be also used as a component.

Source: Business Registers Agency of the Republic of Serbia

Measured in such manner, the data in the given table show that returns from assets and capital are quite satisfactory in trade companies in Serbia, in comparison to the defined comparable industry standards.

Table 12 shows the interest coverage ratio in processing industry and trade companies in Serbia (with international comparisons).

Table 12. Interest coverage ratio of in processing industry and trading companies in Serbia

\begin{tabular}{|c|c|}
\hline & Interest coverage ratio \\
\hline Processing industry & 3.70 \\
\hline 2015 & 6.72 \\
\hline 2016 & 5.20 \\
\hline Trade & 4.67 \\
\hline 2013 & 6.88 \\
\hline 2014 & 8.89 \\
\hline 2015 & 10.37 \\
\hline 2016 & 6.8800 \\
\hline 2017 & 24.23 \\
\hline Median & 12.13 \\
\hline Comparison & \\
\hline CSIMarket: Wholesale Q4 2017 & \\
\hline CSIMarket: Retail Q4 2017 & \\
\hline
\end{tabular}

Note: Calculations performed by the author

Source: Business Registers Agency of the Republic of Serbia and CSIMarket (Retrieved from https://csimarket.com/) (December 14, 2018)

Data in the given table show that the ratio of coverage of interest rates of commercial enterprises in Serbia in the last years of the observed period increased (the financial indebtedness measured by the related assets and capital was decreasing). It is above a defined comparable industry standard. The solvency of trade companies in Serbia is on the rise and at a satisfactory level, taking into account the current general macroeconomic conditions of business. It is, however, at a lower level in relation to the trade of countries of a developed market economy.

Table 13 and Figure 2 show the movement of the ratio between the interest coverage and the financial indebtedness of trading companies in Serbia. 
Table 13. Ratio of interest coverage and financial indebtedness of trade companies in Serbia

\begin{tabular}{|c|c|c|}
\hline & $\begin{array}{c}\text { Interest coverage ratio } \\
\text { (EBIT / Interest) }\end{array}$ & $\begin{array}{c}\text { Financial indebtedness (assets / } \\
\text { capital) }\end{array}$ \\
\hline 2013 & 5.20 & 2.89 \\
\hline 2014 & 4.67 & 2.82 \\
\hline 2015 & 6.88 & 2.74 \\
\hline 2016 & 8.89 & 2.68 \\
\hline 2017 & 10.37 & 2.56 \\
\hline $\begin{array}{c}\text { (CAGR - Compound Annual } \\
\text { Growth Rate) }\end{array}$ & 14.8 & -2.4 \\
\hline
\end{tabular}

Note: Calculations performed by the author

Source: Business Registers Agency of the Republic of Serbia

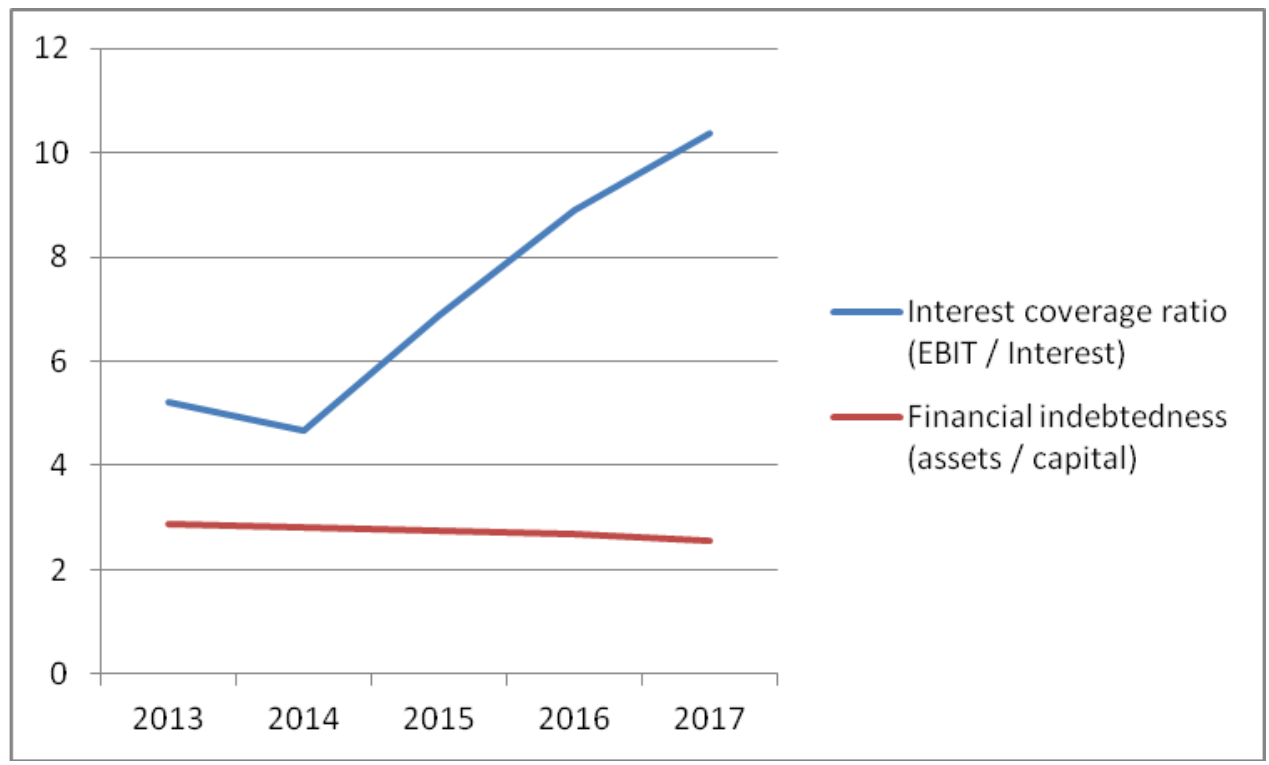

Figure 2. Interest rate coverage and financial indebtedness of trade companies in Serbia

The data in the given table show that the interest coverage ratio increased in the observed period and the financial indebtedness of trading companies in Serbia decreased. This points to the conclusion that their financial stability (i.e. solvency) has increased.

For the purpose of a more complex analysis in Table 14, descriptive statistics of interest coverage and financial indebtedness of trade companies in Serbia are presented. 
Table 14. Descriptive statistics of the interest coverage ratio and financial indebtedness of trade companies in Serbia

\begin{tabular}{|c|c|c|c|}
\hline Descriptive Statistics & Mean & Std. Deviation & N \\
\hline & & & 5 \\
$\begin{array}{c}\text { Interest coverage ratio } \\
\text { (EBIT / interest) }\end{array}$ & 7.2020 & 2.41911 & 5 \\
\hline $\begin{array}{c}\text { Financial indebtedness } \\
\text { (assets / capital) }\end{array}$ & 2.7380 & 0.12736 & \\
\hline
\end{tabular}

Note: Calculation performed by the author, in the SPSS software

The data in the given table show that the interest coverage ratio of trading companies in Serbia is, on average, 7.20. Therefore, it is above a defined comparable industry standard, which means that, according to this indicator, the solvency of trading companies in Serbia is at satisfactory level.

Data in Table 15. Show that there is, at the level of statistical significance, a strong negative correlation between the interest coverage ratio and the financial indebtedness of trading companies in Serbia.

Table 15. Correlation matrix of interest coverage ratio and financial indebtedness of trading companies in Serbia

\begin{tabular}{|c|c|c|c|}
\hline \multicolumn{4}{|l|}{ Correlations } \\
\hline & & $\begin{array}{c}\text { Interest coverage ratio } \\
\text { (EBIT / interest) }\end{array}$ & $\begin{array}{c}\text { Financial } \\
\begin{array}{c}\text { indebtedness (assets / } \\
\text { capital) }\end{array}\end{array}$ \\
\hline \multirow{2}{*}{ Pearson Correlation } & $\begin{array}{l}\text { Interest coverage ratio } \\
\text { (EBIT / interest) }\end{array}$ & 1.000 & -.953 \\
\hline & $\begin{array}{l}\text { Financial indebtedness } \\
\text { (assets / capital) }\end{array}$ & -.953 & 1.000 \\
\hline \multirow{2}{*}{ Sig. (1-tailed) } & $\begin{array}{l}\text { Interest coverage ratio } \\
\text { (EBIT / interest) }\end{array}$ & . & .006 \\
\hline & $\begin{array}{l}\text { Financial indebtedness } \\
\text { (assets / capital) }\end{array}$ & .006 & . \\
\hline \multirow{2}{*}{$\mathrm{N}$} & $\begin{array}{l}\text { Interest coverage ratio } \\
\text { (EBIT / interest) }\end{array}$ & 5 & 5 \\
\hline & $\begin{array}{l}\text { Financial indebtedness } \\
\text { (assets / capital) }\end{array}$ & 5 & 5 \\
\hline
\end{tabular}

Note: Calculations performed by the author in SPSS software 
For the purposes of regression analysis, the interest coverage ratio of trade companies in Serbia will define the regression linear function as:

$$
Y_{i}=a+b X_{i}+e_{i} i=1, \ldots, n
$$

where: $\mathrm{Y}=$ dependent variable (interest coverage ratio), $\mathrm{X}=$ independent variable (financial indebtedness), and $\mathrm{b}=$ regression coefficients, and $\mathrm{e}=$ random error.

Table 16 and Figure 3 show the results of the regression analysis of the interest coverage ratio and the financial indebtedness of trading companies in Serbia.

Table 16. Regression analysis of the interest coverage ratio and financial indebtedness of trading companies in Serbia

Model Summary ${ }^{b}$

\begin{tabular}{|c|c|c|c|c|c|c|c|c|c|c|}
\hline \multirow{2}{*}{ Model } & \multirow{2}{*}{$\mathbf{R}$} & \multirow{2}{*}{$\begin{array}{c}\mathbf{R} \\
\text { Square }\end{array}$} & \multirow{2}{*}{$\begin{array}{l}\text { Adjusted } \\
\text { R Square }\end{array}$} & \multirow{2}{*}{$\begin{array}{l}\text { Std. Error } \\
\text { of the } \\
\text { Estimate }\end{array}$} & \multicolumn{5}{|c|}{ Change Statistics } & \multirow{2}{*}{$\begin{array}{l}\text { Durbin- } \\
\text { Watson }\end{array}$} \\
\hline & & & & & $\begin{array}{c}\text { R Square } \\
\text { Change }\end{array}$ & \begin{tabular}{|c|}
$\mathbf{F}$ \\
Change
\end{tabular} & df1 & df2 & $\begin{array}{c}\text { Sig. F } \\
\text { Change }\end{array}$ & \\
\hline 1 & $.953^{\mathrm{a}}$ & .908 & .877 & .84677 & .908 & 29.647 & 1 & 3 & .012 & 2.391 \\
\hline
\end{tabular}

a. Predictors: (Constant), Financial indebtedness (assets / capital)

b. Dependent Variable: interest coverage ratio (EBIT / interest)

ANOVA $^{\mathrm{a}}$

\begin{tabular}{|l|l|l|l|l|l|l|}
\hline \multicolumn{2}{|c|}{ Model } & Sum of Squares & df & Mean Square & F & Sig. \\
\hline \multirow{3}{*}{1} & Regression & 21.257 & 1 & 21.257 & 29.647 & $.012^{\text {b }}$ \\
\cline { 2 - 8 } & Residual & 2.151 & 3 & .717 & & \\
\cline { 2 - 7 } & Total & 23.408 & 4 & & & \\
\hline
\end{tabular}

a. Dependent Variable: interest coverage ratio (EBIT / interest)

b. Predictors: (Constant), Financial indebtedness (assets / interest)

Coefficients ${ }^{\text {a }}$

\begin{tabular}{|c|c|c|c|c|c|c|}
\hline & \multirow{2}{*}{ Model } & \multicolumn{2}{|c|}{ Unstandardized Coefficients } & \multirow{2}{*}{$\begin{array}{c}\text { Standardized } \\
\text { Coefficients }\end{array}$} & \multirow{2}{*}{$\mathbf{t}$} & \multirow{2}{*}{ Sig. } \\
\hline & & B & Std. Error & & & \\
\hline \multirow[b]{2}{*}{1} & (Constant) & 56.762 & 9.110 & & 6.231 & .008 \\
\hline & $\begin{array}{l}\text { Financial } \\
\text { indebtedness } \\
\text { (assets } \\
\text { capital) }\end{array}$ & -18.101 & 3.324 & -.953 & -5.445 & .012 \\
\hline
\end{tabular}

a. Dependent Variable: Interest coverage ratio (EBIT / interest)

Note: Calculations performed by the author in SPSS software 
The data in the given table show that the correlation between the interest coverage ratio and the financial indebtedness of trading companies in Serbia (Adjusted R Square =.877; Sig. F Change $=.012$ ) is strong at the level of statistical significance. There is no autocorrelation in the regression analysis ratios (Durbin-Watson $=2.391$ ). Regression coefficients are at the level of statistical significance $(($ Constant $)=$ Sig. .008; Financial indebtedness $($ assets / capital $)=$ Sig., 012). The regression linear function is therefore:

$$
\mathrm{Y}=56.762-18.101 \mathrm{X}
$$

Future expectations can be established through this regression.

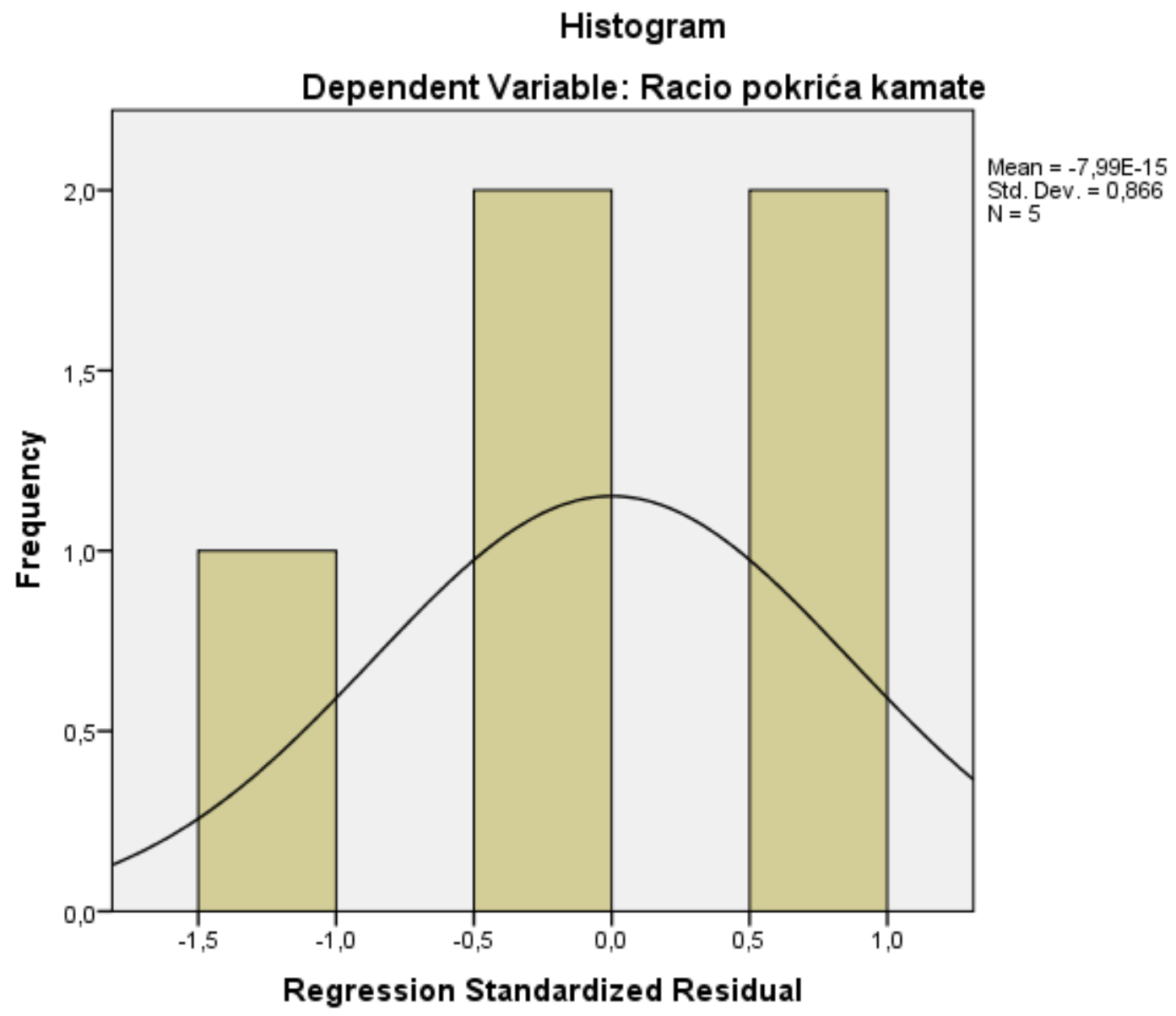

Figure 3. Histogram of the interest coverage ratio of trading companies in Serbia

\section{INTEREST RATES FOR SELECTIVE RETAILERS IN SERBIA}

In order to make a more complex analysis of the issues discussed in this paper, we will look at the dynamics of interest costs of Delhaize Serbia and Mercator-S. These two companies are the most important retailers in Serbia (according to the realized business revenues in 2017). Table 17 
shows the dynamics of interest costs of Delhaize Serbia and Mercator-S, and some global retail chains for the purpose of international comparisons.

Table 17. Interest costs of selected retailers in Serbia

\begin{tabular}{|c|c|c|c|c|c|c|c|c|c|c|}
\hline & \multicolumn{5}{|c|}{ Delhaize Serbia } & \multicolumn{5}{|c|}{ Mercator-S } \\
\hline & $\begin{array}{c}\text { Revenues } \\
\text { (million } \\
\text { dinars) }\end{array}$ & $\begin{array}{l}\text { Interest } \\
\text { cost } \\
\text { (million } \\
\text { dinars) }\end{array}$ & $\begin{array}{c}\text { Interest } \\
\text { costs }(\% \\
\text { of } \\
\text { revenues)* }\end{array}$ & $\begin{array}{c}\text { Interest } \\
\text { revenues } \\
\text { (million } \\
\text { dinars) }\end{array}$ & \begin{tabular}{|c|} 
Net \\
interest \\
costs \\
(million \\
dinars)
\end{tabular} & $\begin{array}{c}\text { Revenues } \\
\text { (million } \\
\text { dinars) }\end{array}$ & $\begin{array}{l}\text { Interest } \\
\text { costs } \\
\text { (million } \\
\text { dinars) }\end{array}$ & $\begin{array}{c}\text { Interest } \\
\text { costs }(\% \\
\text { revenues) } *\end{array}$ & \begin{tabular}{|c} 
Interest \\
revenues \\
(million \\
dinars)
\end{tabular} & \begin{tabular}{|c|} 
Net \\
interest \\
costs \\
(million \\
dinars)
\end{tabular} \\
\hline 2014 & 74.943 & 13 & 0,02 & 179 & 166 & 72.554 & 555 & 0,76 & 68 & 487 \\
\hline 2015 & 77.383 & 11 & 0,01 & 239 & 228 & 112.229 & 975 & 0,87 & 83 & 892 \\
\hline 2016 & 85.025 & 1 & 0,00 & 215 & 214 & 100.042 & 1.247 & 1,24 & 64 & 1.183 \\
\hline 2017 & 94.884 & 1 & 0,00 & 410 & 409 & 90.747 & 1.314 & 1,45 & 12 & 1.302 \\
\hline $\begin{array}{c}\text { Global } \\
\text { retailers }\end{array}$ & & & $\begin{array}{c}\text { Interest } \\
\text { costs }(\% \\
\text { from } \\
\text { revenues }) \\
2017\end{array}$ & & & & & & & \\
\hline $\begin{array}{l}\text { Wal-Mart } \\
\text { Q4 } 2017 \\
\end{array}$ & & & 0.47 & & & & & & & \\
\hline $\begin{array}{c}\text { Target Q4 } \\
2017\end{array}$ & & & 0.92 & & & & & & & \\
\hline $\begin{array}{c}\text { Kroger Co. } \\
\text { Q4 } 2017\end{array}$ & & & 0.49 & & & & & & & \\
\hline Tesco & & & 1.56 & & & & & & & \\
\hline Carrefour & & & 0.40 & & & & & & & \\
\hline $\begin{array}{c}\text { Ahold } \\
\text { Delhaize }\end{array}$ & & & 0.46 & & & & & & & \\
\hline $\begin{array}{c}\text { X5 Retail } \\
\text { Group }\end{array}$ & & & 1.16 & & & & & & & \\
\hline
\end{tabular}

Source: Business Registers Agency of the Republic of Serbia, CSIMarket (Retrieved from https://csimarket.com/)

(December 14, 2018), and Annual Report Tesco 2017, Annual Report Carrefour 2017, Annual Report Ahold Delhaize 2017, X5 Retail Group Annual Report 2017 (Retrieved from https://ar2017.x5.ru/en) (December 24, 2018)

The data in the given table show that the interest costs in Delhaize Serbia decreased in the observed period, and increased with Mercator-S from year to year. In 2017, interest costs in percentages of revenues are higher in the company Mercator-S, and lower in Delhaize Serbia in comparison to the observed global retail chains (Wal-Mart, Target, Kroger Co.).

Table 18 shows the interest coverage ratio of selected retailers in Serbia in 2017.

Table 18. Interest coverage ratio of selected retailers in Serbia, 2017

\begin{tabular}{|c|c|c|c|c|c|}
\hline & $\begin{array}{c}\text { Net profit } \\
\text { (million } \\
\text { dinars) }\end{array}$ & $\begin{array}{c}\text { Interest } \\
\text { (million } \\
\text { dinars) }\end{array}$ & $\begin{array}{c}\text { Tax (million } \\
\text { dinars) }\end{array}$ & $\begin{array}{c}\text { Earnings } \\
\text { before interest } \\
\text { and tax (EBIT) } \\
\text { (million } \\
\text { dinars)* }\end{array}$ & $\begin{array}{c}\text { Interest } \\
\text { coverage ratio } \\
\text { (Earnings } \\
\text { before interest } \\
\text { and tax / } \\
\text { Interest)* }\end{array}$ \\
\hline Delhaize Serbia & 4.264 & 1 & 237 & 4.502 & 4.502 \\
\hline Mercator-S & $(6851)$ & 1.314 & 144 & $(5.393)$ & $(4.10)$ \\
\hline
\end{tabular}




\begin{tabular}{|c|c|c|c|c|c|}
\hline & $\begin{array}{c}\text { Net profit } \\
\text { (million } \\
\text { dinars) }\end{array}$ & $\begin{array}{c}\text { Interest } \\
\text { (million } \\
\text { dinars) }\end{array}$ & $\begin{array}{c}\text { Tax (million } \\
\text { dinars) }\end{array}$ & $\begin{array}{c}\text { Earnings } \\
\text { before interest } \\
\text { and tax (EBIT) } \\
\text { (million } \\
\text { dinars)* }\end{array}$ & $\begin{array}{c}\text { Interest } \\
\text { coverage ratio } \\
\text { (Earnings } \\
\text { before interest } \\
\text { and tax / } \\
\text { Interest)* }\end{array}$ \\
\hline Global retailers & & & & & \\
\hline Wal-Mart & & & & & 9.08 \\
\hline Target & & & & & 13.74 \\
\hline Kroger Co. & & & & & 10.99 \\
\hline X5 Retail Group & & & & 3.77 \\
\hline
\end{tabular}

Note: *Calculation performed by the author

Source: Business Registers Agency of the Republic of Serbia, CSIMarket (Retrieved from https://csimarket.com/)

(December 14, 2018) and X5 Retail Group Annual Report 2017 (Retrieved from https://ar2017.x5.ru/en) (December 24, 2018)

The data in the given table show that the interest coverage ratio of selected retailers in Serbia is lower compared to the observed global retailers. This is, among other things, the result of more unfavourable general conditions of business in Serbia. In addition to the unfavourable financial structure, we need to add that there is also a lower level of implementation of modern concepts of business as well as modern technology in the retail market of Serbia.

\section{CONCLUSIONS}

For trade companies in Serbia, there is a tendency of reducing interest costs. This was influenced by numerous factors, among other things, by reducing the banking interest rate, a stable exchange rate and improving general business conditions.

There is a tendency of increasing interest coverage ratio in trading companies in Serbia. It is slightly higher than a defined comparable industry standard. In view of this, the solvency of trading companies in Serbia is increasing.

According to the realized business income in 2017 in Serbia, the two most important retailers are Delhaize Serbia and Mercator-S. The general conclusion is that their interest coverage ratio is lower than with the global retailers such as Wal-Mart, Target and Kroger Co. This is due to the fact that there are unfavourable structures of the capital of the observed retailers in Serbia.

\section{REFERENCES}

Berman, B.\&Evans, J. R. (2013). Retail Management. Boston: Prentice Hall.

Calva, A. (2017). Case of financial ratio analysis: Food retail industry in Canada (20122016).Acus Consulting Ltd., 1-13.

Cârstea, G., Corbos, R.A., Popescu, R.I. \&Bunea, O.I. (2017). Analysis of the influence ofsome indicators on the profitability of the FMCG retail market in Romania, inPopa I. Dobrin C., Ciocoiu C.N. (editors): Proceedings of the $11^{\text {th }}$ International Management Conference. The Role of Management in the Economic Paradigm of the XX-st Century, November $2^{\text {nd }}-4^{\text {th }}$, 2017, Bucharest, Romania, 481-492.

Corona, R. (2014). Comparative Analysis of Major US Retailers Based on Enterprise MarketingEfficiency. Global Business research, 8(4), 25-39. 
Gülşah, H., AlperŞ. \&EsraA. A. (2016). Demand uncertainty and inventory turnover performance: An empirical analysis of the US retail industry. International Journal of Physical Distribution \& Logistics Management, 46(6/7), 681-708.

Hoe, L.W., Siew; L.W., Wai, C.J. (2017). A Study on the Performance of the Retailers in Malaysis with TOPSUS Model. International Journal of Economic Theory and Application, 5(1), 7-12.

Ko, K., Chang, M., Bae, E.S. \&Kim, D. (2017). Efficiency Analysis of Retail Chain Stores inKorea. Sustainability, 9(9), 16-29.

Levy, M. Weitz. B. A. \& Grewal. D. (2014). Retailing Management. New York: McGraw-Hill.

Lukic, R. (2017a). The Impact of Margin on the Performance of Trade Companies in Serbia.LIMES plus: Journal of Social Sciences and Humanities, 3, 49-71.

Lukic, R. \&Sokic, M. (2017b). Efficiency Analysis of Trade Capital Management in Serbia.Management Research and Practice, 9(4), 38-47.

Manini, R. \&Amat, O. (2017). Credit Scoring for the Supermarket and Retailing Industry: Analysis and Application Proposal. European Accounting and Management Review, 4(1), 75-88.

Sui, Y. (2017). The Research on the Applications and Limitations of EBITDA. 2017

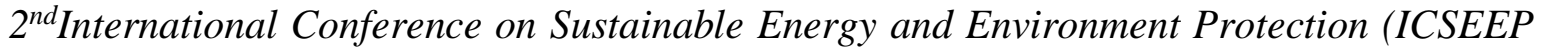
2017), 66-69.

Špička, J. (2016). Market Concentration and Profitability of the Grocery Retailers in CentralEurope. Central European Business Review, 5(3), 5-24.

Susmus, T. \&Baslangiç, O. S. (2017). Income and Expense Analysis of Retail Trade Sector Companies Traded on Borsa Istanbul. World, KnE Social Sciences, EBEEC Conference Proceedings, The Economies of Balkan and Eastern Europe Countries in the Changed, 357-365. DOI 10.18502/kss.v1i2.669.

Tan, Z. (2016). Application of Discounted Cash Flow Model Valuation - Wal-Mart. MPRA Paper No. 83903, 1-16. 